\title{
DEVELOPMENT OF SIMPLE INFRASTRUCTURE TO ENHANCE SUSTAINABLE DEVELOPMENT IN PASIR MULYA TOURISM VILLAGE
}

\author{
Oki Setyandito $^{1 *}$, Irpan Hidayat ${ }^{1}$, Putri Arumsari ${ }^{1}$, Adelia D.Nataadmadja ${ }^{1}$, Juliastuti ${ }^{1}$ \\ ${ }^{1}$ Department of Civil Engineering, Faculty of Engineering, Bina Nusantara University, Jakarta. 11480 \\ *osetyandito@binus.edu
}

\begin{abstract}
Pasir Mulya Tourism Village Sustainable Development in Bandung Regency is one of the programs of Binus Bangun Desa. Some developments have been conducted in this village such as the reconstruction of sanitation facilities of rented houses, the development of small/middle size entrepreneurship economics, and etc. This study was performed based on the discussion between the community, village officers, and the chief of the village and also the survey conducted by our team. The survey was conducted on the types of simple infrastructures and urgent needs of the village. Based on the survey it is shown that the needs of the community were trainings and assistance. The assistance were regarding the understanding of prevention acts during natural disasters such as earthquake and landslide. The trainings needed were regarding how to design a simple earthquake proof house, design and repair village roads and design water distribution system with a storage pond. This paper will present a future action plan to enhance the development and programs that have been conducted in Pasir Mulya village.
\end{abstract}

Keywords: Pasir Mulya, simple infrastruction, action plan, assistance, training

\section{INTRODUCTION}

Village has many potential to enhance its economical situation. Villages, in rural area and especially in Indonesia, show its ability to support their life. However, some villages could not meet its maximum potential due to lack of infrastructures. Kampung Wangun is located at Pasirmulya Village, The previous programs were: training and knowledge sharing about the evacuation plan of earthquake and landslide disaster; positioning the safety signs for meeting place at the determined open space area; and training of design and construction of simple earthquake proof buildings.

Kampung Wangun has potentials to become a tourism village. Coffee is the main commodity in this Kampung. Therefore, it became the pilot project for 9 (nine) other Kampungs with their own other kind of commodities.

The development of economic sector must be supported by good infrastructures, such as, transportation infrastructure and other infrastructures. Sometimes, the success of one kampung will be followed by other kampungs near by. National Community Development Program (Program Nasional Pemberdayaan Masyarakat, PNPM Mandiri Program) has been conducted in year 2015. As a result, many village infrastructures such as road, bridges and sanitation facilities (Setyandito, 2018). Some studies have been performed on enhancing the performance of PNPM in village in Kabupaten Bandung from year 2009 to 2013. This study was a successful program with the objective to share experience and knowledge with national and regional government. These acquired knowledge and experience could be utilized to improve the PNPM Mandiri Village Program or other similar community development programs. Hence, these programs could reduce poverty at present and/or in future (Zulfida, Fauzi, Rustiadi, \& Syaukat, 2015).

Pasirmulya village has a hilly topographycal feature; therefore, suitable infrastructures are needed. These infrastructures are not available at the moment. Moreover, due to its earthquake prone location, some aspects must be taken into consideration such as: disaster mitigation procedures, quality of building, community awareness and preparednes regarding natural disaster such as earthquake and 
landslides (Setyandito, 2018). Sharing knowledge and experiences programs have been conducted in kampung Wangon, such as: training and knowledge sharing about the evacuation plan of earthquake and landslide disaster; positioning the safety signs for meeting place at the determined open space area; and training of design and construction of simple earthquake proof buildings.

\section{Study Area}

Pasirmulya is located in Banjaran district, Bandung regency, West Java, with hilly topographical condition. Pasir mulya village is positioned on the Lembang and Cimandiri earth's plate (Figure 1). This situation caused the village in a disaster prone area. Therefore, communities need to be informed and dissemination of emergency precaution that should be conducted during earthquake and landslide occurrence. To minimize the casualties caused by natural disaster, simple house counstruction design with earthquake proof approach can be applied. This design should be taught to the community. Present condition of infrastructures in Pasirmulya village is shown in Figure 2. Preliminary field survey in this area shows village road condition (Figure.2.a) where during rainfall occurrence, this road could not be access by motorcycles and cars due to its steep and slippery road surface. The survey also revealed that some soil retaining walls are prone to collapse due to landslide. These retaining wall are located near the housing area therefore, enhancement of retaining wall strength is a must. Some public buildings such as, chief of the village meeting place, and some people's houses are in need of reconstruction to prevent future damage caused by earhquake (Figure 4). Toilet and bathroom also improved to assured access to sanitation. Tiling the floor in some houses should be conducted, as well as, renovation of some houses on up hill area. During long dry season, some rivers are dry, hence the solution for this problem is proposed to cope the impact of climate change. Simple water distribution system is designed to fulfil water need of the community in dry season. The detail of activities required for Pasir mulya village can be seen in Table 1.

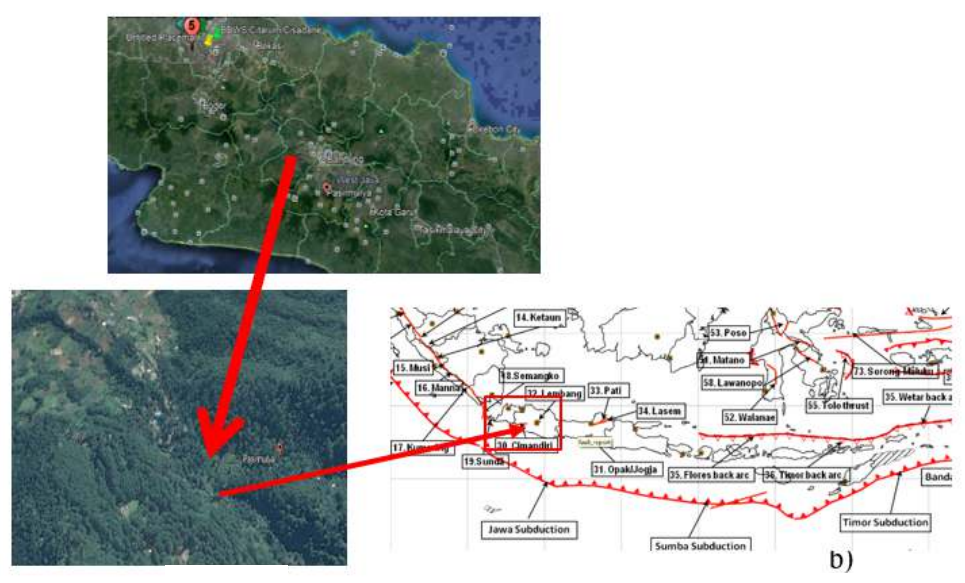

a)

b)

Figure 1. PasirMulya, Puntang, Kabupaten Bandung Jawa Barat (a) and Pasirmulya village location on earth's plate of Lembang and Cimandiri

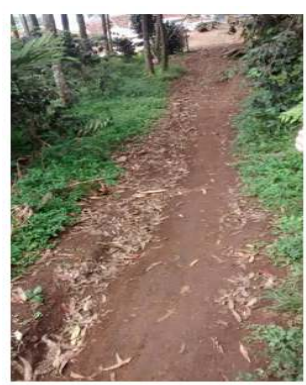

a)

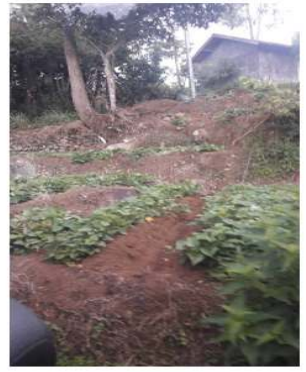

b)

Figure 2. Condition of village road, soil road, steep and slippery during rainfall occurrence (a) and landslide prone retaining wall near housing area 


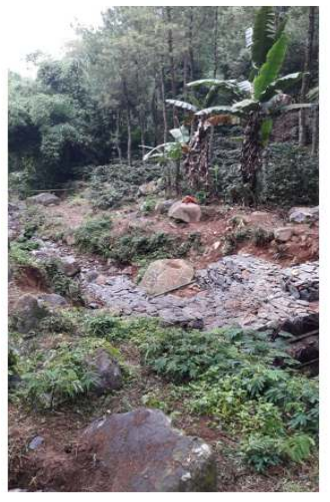

a)

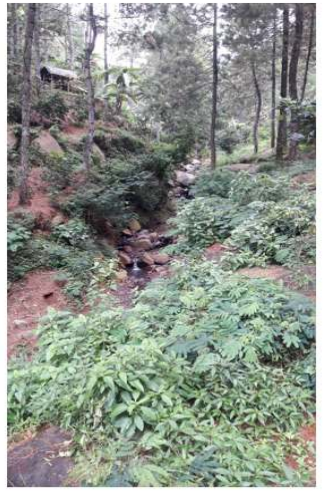

b)

Figure 3. Dry river during dry season

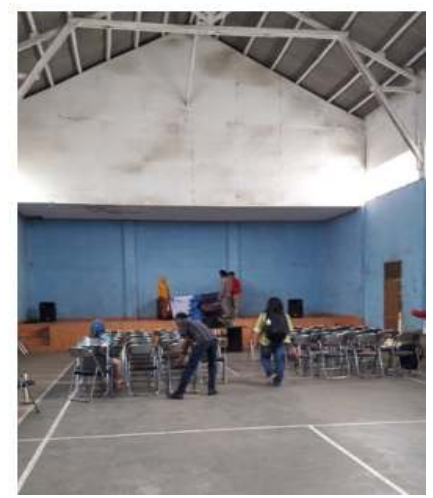

Figure 4. Community meeting place that needs renovation and structure strength investigation due to earthquake and landslide disaster occurrence

Table 1. Problems and types of activities and community involvement in development and renovation of infrastructure in Binus Bangun Desa at Pasirmulya village

\begin{tabular}{|c|c|c|c|c|c|}
\hline Type & Problem & Activity & Detail activity & Time & Note \\
\hline \multirow[t]{2}{*}{$\begin{array}{l}\text { Mitigation } \\
\text { of } \\
\text { earthquake } \\
\text { and } \\
\text { landslide } \\
\text { disaster }\end{array}$} & $\begin{array}{l}\text { No } \\
\text { evacuation } \\
\text { map }\end{array}$ & $\begin{array}{l}\text { 1.Dissemination } \\
\text { and Sharing } \\
\text { knowledge } \\
\text { 2. Development of } \\
\text { evacuation map } \\
\text { for earthquake } \\
\text { an landslide } \\
\text { disaster }\end{array}$ & $\begin{array}{l}\text { 1. Dissemination and Sharing } \\
\text { knowledge on how to } \\
\text { mitigate the disaster and } \\
\text { simple earthquake proof } \\
\text { house } \\
\text { 2. Development of evacuation } \\
\text { map for earthquake an } \\
\text { landslide disaster }\end{array}$ & $\begin{array}{l}\text { February, } \\
\text { April, } \\
\text { August } \\
2018\end{array}$ & $\begin{array}{l}\text { Done, active } \\
\text { participation } \\
\text { from the } \\
\text { community } \\
\text { which } \\
\text { coordinated } \\
\text { by village } \\
\text { officers }\end{array}$ \\
\hline & $\begin{array}{l}\text { Lack of } \\
\text { knowledge } \\
\text { on how to } \\
\text { evacuate }\end{array}$ & $\begin{array}{l}\text { 1. Dissemination } \\
\text { and sharing } \\
\text { knowledge } \\
\text { 2. Installment of } \\
\text { safety sign s }\end{array}$ & $\begin{array}{l}\text { 1. Dissemination and Sharing } \\
\text { knowledge on how to } \\
\text { mitigate the disaster } \\
\text { 2. Installment of safety sign by } \\
\text { comdev Binus team and } \\
\text { instalment of meeting safety } \\
\text { sign by the community }\end{array}$ & $\begin{array}{l}\text { April, } \\
\text { August } \\
2018\end{array}$ & $\begin{array}{l}\text { Done, active } \\
\text { participation } \\
\text { from the } \\
\text { community } \\
\text { which } \\
\text { coordinated } \\
\text { by village } \\
\text { officers }\end{array}$ \\
\hline $\begin{array}{l}\text { Landslide } \\
\text { Mitigation }\end{array}$ & $\begin{array}{l}\text { 1. Lack of } \\
\text { knowled } \\
\text { ge on } \\
\text { how to }\end{array}$ & $\begin{array}{l}\text { 1. Counseling dan } \\
\text { Sharing } \\
\text { knowledge }\end{array}$ & $\begin{array}{l}\text { 1. Dissemination and Sharing } \\
\text { knowledge on how to } \\
\text { mitigate landslide disaster } \\
\text { 2. Training on designing a } \\
\text { simple retaining wall }\end{array}$ & $\begin{array}{l}\text { April, } \\
\text { August } \\
2018\end{array}$ & $\begin{array}{l}\text { Done, active } \\
\text { participation } \\
\text { from the } \\
\text { community } \\
\text { which }\end{array}$ \\
\hline
\end{tabular}




\begin{tabular}{|c|c|c|c|c|c|}
\hline Type & Problem & Activity & Detail activity & Time & Note \\
\hline & $\begin{array}{c}\text { 2. Urgent } \\
\text { nedd to } \\
\text { understan } \\
\text { d the } \\
\text { dangerous } \\
\text { land slope } \\
\text { that prone } \\
\text { to }\end{array}$ & $\begin{array}{c}\text { 2. Instalment of } \\
\text { meeting point } \\
\text { safety sign } \\
\text { 3raining on } \\
\text { designing a } \\
\text { simple retaining } \\
\text { wall }\end{array}$ & $\begin{array}{c}\text { 3. Installment of safety sign by } \\
\text { comdev Binus team and } \\
\text { instalment of meeting safety } \\
\text { sign by the community }\end{array}$ & & $\begin{array}{l}\text { coordinated } \\
\text { village } \\
\text { officers }\end{array}$ \\
& & & & & \\
& & & & \\
\end{tabular}

\section{METHOD}

The first phase is desk study and survey investigation of village road infrastructure and other infrastructures. Scoring system was applied to determine whether the infrastructures meet its fuction. Also, its potential to collapse was identified thoroughly after the preliminary survey (Merritt \& Jonathan, 2000). From preliminary survey result, analyses on infrastructures that need to be renovated were identified.

The phases of this research are as follows (Setyandito, 2018):

1) Problem identification based on community development topic determined

2) Literature study on the simple infrastructure and previous studies or theories on the identified problems and its solutions alternatives

3) Determination of parameter design of study result and trainings, and development of construction design in tourism village area.

Some solution alternatives that being proposed are: training, sharing knowledge, and activities of dissemination on renovation, simple infrastructure construction, and earthquake proof building. In this study, analysis method applied is descriptive analysis approach (Dewi, Fandeli, \& Baiqumi, 2013).

Traditional civil engineering approach is determined as the basic knowledge for the simple infrastructure concept. Implementation in the field is using construction management theory which is modification among stakeholders such as, a contractor (self-finance and supported), a designer (the team from Binus community development and the community) also an owner (the community). These stakeholders are inter-connected with rensponsibilities to carry out the program (Merritt \& Jonathan, 2000) \& (Yu, Shen, Qiping, \& Shi, 2017).

\section{RESULT AND DISCUSSION}

The participation of local community is a must in each phases of the program, from designing, implementation, and monitoring activitiy (Dewi, Fandeli, \& Baiqumi, 2013).The phases in renovation and development of infrastructure is shown in Figure 5. Some problems and solutions applied are in alignment with community development Binus university programes, where involvement of community is a must, as shown in Table 1. It shows types of activities and its time schedule. The activities that are already conducted are:

1. Dissemination and sharing knowledge on disaster mitigation and earthquake proof simple house structure

2. Evacuation map during earthquake and landslide

3. Installment of safety sign by comdev Binus team and meeting point safety sign by the community

4. Dissemination and sharing knowledge on how to mitigate landslide disaster, training on how to design a simple retaining wall.

5. Dissemination and sharing knowledge on how to design simple village road sederhana. 
Table 2. Problems and types of activities and community involvement in development and renovation of infrastructure in Binus Bangun Desa at Pasirmulya village

\begin{tabular}{|c|c|c|c|c|c|}
\hline Type & Problem & Activity & Detail activity & Time & Note \\
\hline $\begin{array}{l}\text { Infrastruc } \\
\text { ture } \\
\text { village } \\
\text { road and } \\
\text { retaining } \\
\text { wall }\end{array}$ & $\begin{array}{l}\text { 1. Lack of } \\
\text { knowledge on } \\
\text { how to evacuate } \\
\text { and introduction } \\
\text { to meeting point } \\
\text { 2. The need for } \\
\text { introduction to } \\
\text { designing a } \\
\text { simple village } \\
\text { road and } \\
\text { retaining wall } \\
\text { 3. The need for } \\
\text { introduction to } \\
\text { simple village } \\
\text { road } \\
\text { construction }\end{array}$ & $\begin{array}{l}\text { 1. Disseminatio } \\
\mathrm{n} \text { and Sharing } \\
\text { knowledge } \\
\text { 2. Training of } \\
\text { designing a } \\
\text { simple village } \\
\text { road and } \\
\text { retaining wall } \\
\text { 3. Training on } \\
\text { maintenance } \\
\text { and op rotional of } \\
\text { operation road } \\
\text { village retaining } \\
\text { and rall }\end{array}$ & $\begin{array}{l}\text { 1. Dissemination } \\
\text { and Sharing } \\
\text { knowledge of } \\
\text { designing } \\
\text { simple village } \\
\text { road and } \\
\text { retaining wall } \\
\text { 2. Material and } \\
\text { construction of } \\
\text { village road } \\
\text { and retaining } \\
\text { wall }\end{array}$ & $\begin{array}{l}\text { 1. Sharing } \\
\text { knowledge } \\
\text { and } \\
\text { training } \\
\text { (April } \\
\text { 2018) } \\
\text { 2. material } \\
\text { and } \\
\text { constructio } \\
\text { n of village } \\
\text { road and } \\
\text { retaining } \\
\text { wall } \\
\text { (not yet) }\end{array}$ & $\begin{array}{l}\text { No } 1 . \text { Done, } \\
\text { active } \\
\text { participation from } \\
\text { the community } \\
\text { which coordinated } \\
\text { by village officers } \\
\text { No } 2 \text {. Not yet, it } \\
\text { will be perform if } \\
\text { get the funding } \\
\text { support from } \\
\text { donation/proposal } \\
\text { / CSR, or } \\
\text { government }\end{array}$ \\
\hline $\begin{array}{l}\text { Infrastruc } \\
\text { ture } \\
\text { distributi } \\
\text { on of } \\
\text { sistem } \\
\text { and } \\
\text { sanitation }\end{array}$ & $\begin{array}{l}\text { The need for } \\
\text { introduction to } \\
\text { designing an } \\
\text { Infrastructure of } \\
\text { distribution sistem } \\
\text { and sanitation }\end{array}$ & $\begin{array}{l}\text { 1. Disseminatio } \\
\mathrm{n} \text { and sharing } \\
\text { knowledge } \\
\text { 2. Constructuion } \\
\text { of pond and } \\
\text { water } \\
\text { distribution } \\
\text { system }\end{array}$ & $\begin{array}{l}\text { 1. Pelatihan } \\
\text { desain } \\
\text { bangunan } \\
\text { Sistem } \\
\text { distribusi air } \\
\text { bersih dan } \\
\text { sanitasi } \\
\text { 2. material and } \\
\text { construction of } \\
\text { pond and } \\
\text { water } \\
\text { distribution } \\
\text { system }\end{array}$ & Not yet & Not yet \\
\hline $\begin{array}{l}\text { Rehabilit } \\
\text { ation of } \\
\text { simple } \\
\text { earthquak } \\
\text { e proof } \\
\text { house } \\
\text { structure } \\
\text { and } \\
\text { cement } \\
\text { flooring }\end{array}$ & $\begin{array}{l}\text { The need of } \\
\text { introduction to } \\
\text { simple earthquake } \\
\text { proof house } \\
\text { structure and } \\
\text { cement flooring }\end{array}$ & $\begin{array}{l}\text { Training and } \\
\text { sharing } \\
\text { knowledge }\end{array}$ & $\begin{array}{l}\text { 1. Training on } \\
\text { how to design } \\
\text { a simple } \\
\text { earthquake } \\
\text { proof house } \\
\text { and cement } \\
\text { flooring } \\
\text { 2. material and } \\
\text { construction of } \\
\text { prone house } \\
\text { structure and } \\
\text { cement } \\
\text { flooring }\end{array}$ & Not yet & Not yet \\
\hline
\end{tabular}

Some activities that are not yet being done are material and village road construction, simple retaining wall construction, earthquake prone building investigation, storage pond and water distribution system construction. The scheme of how the infrastructure development will be performed is shown in Figure 5. In his scheme, the coordination process is implemented before, during and after the construction activity. 


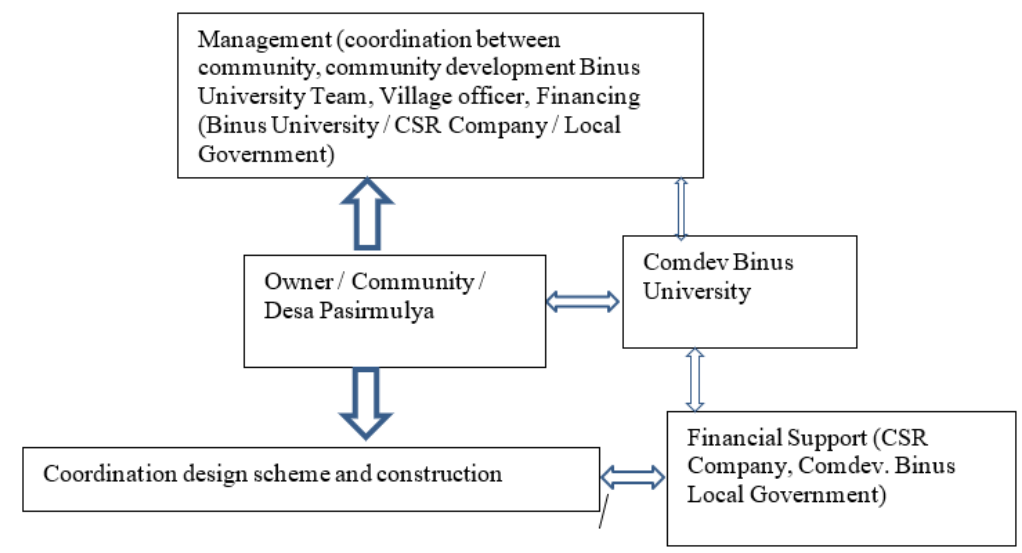

Figure 5. Scheme of coordination flow of infrastructure development (Theoretical development based on Yu, Shen, Qiping \& Shi, 2017)

\section{Mitigation and Training Method}

Figure 6. shown the dissemination and knowledge sharing in the community. It involves the community, village officers and community development Binus University team. The map of evacuation plan and meeting point during earthquake and landslide is presented in Figure 7.
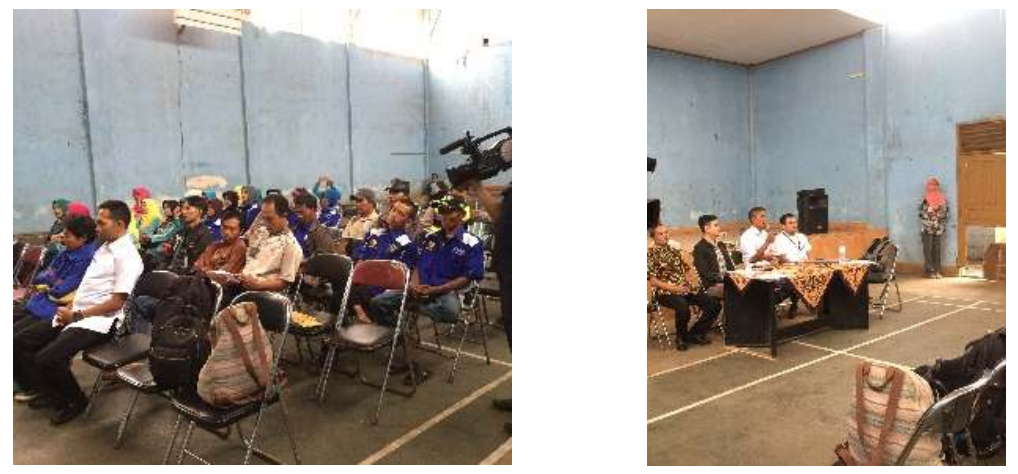

Figure 6. Training on how to mitigate earth quake and simple earthquake prone

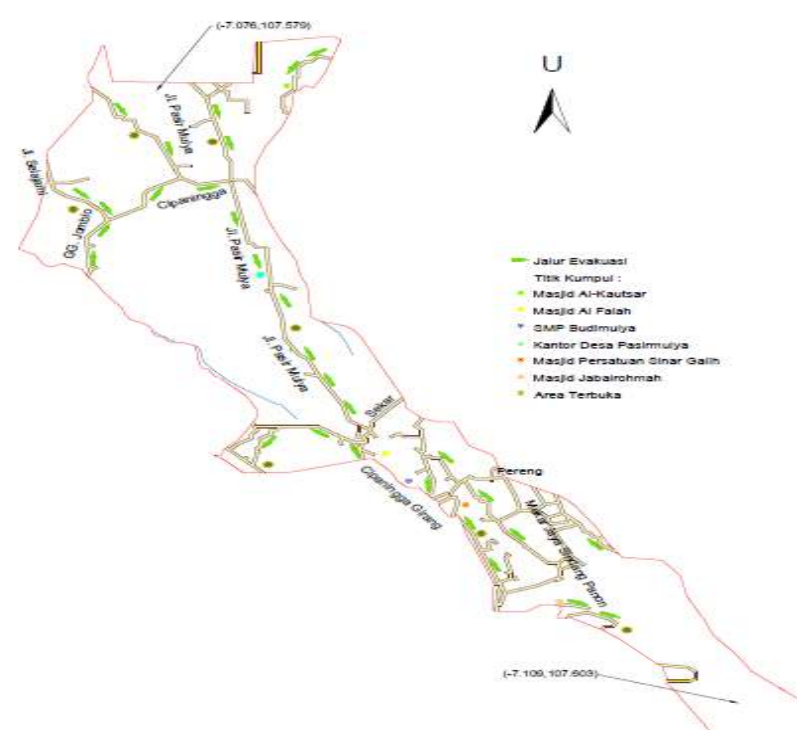

Figure 7. Map of disaster evacuation and meeting point 


\section{CONCLUSION}

1. The effective activities in knowledge transfer process on infrastructure development and disaster mitigation in Pasirmulya village are training and sharing knowledge activities by participatory method of both the community and village officers.

2. Activities in tourism village that already conducted at present are: dissemination and sharing knowledge on how to mitigate the natural disaster and simple earthquake proof house structure, how to mitigate landslide disaster, how to design simple village road and training on how to design simple retaining wall

3. Development of earthquake and landslide evacuation map and instalment of meeting point sign also being performed by Community Development (Comdev) Binus and the community.

4. Training on effective water distribution system should be conducted in future

5. Implementation in the field is using construction management theory which is modification among stakeholders such as, a contractor (self-finance and supported), a designer (the team from Binus community development and the community) also an owner (the community). These stakeholders are inter-connected with rensponsibilities to carry out the program

\section{REFERENCES}

Dewi, M., Fandeli, C., \& Baiqumi, M. (2013). Pengembangan Desa Wisata Berbasis Partisipasi Masyarakat Lokal di Desa Wisata Jatiluwuh Tabanan, Bali. Jurnal Kawistara, 177-226.

Merritt, F., \& Jonathan, T. (2000). Building Design and Construction Handbook. USA: McGraw-Hill.

Setyandito, O. (2018). Studi Perbaikan Infrastruktur Jalan Lingkungan, Jembatan dan Perkuatan Tebing Desa Wisata Pasir Mulya, Banjara, Jawa Barat. DKI Jakarta: Fakultas Teknik, Bina Nusantara University.

Yu, T., Shen, G., Qiping, \& Shi, Q. (2017). Comparing the Performance Quality of Design-Bid-Build and Design-Build Delivery Methods. Journal of Construction and Engineering Management.

Zulfida, I., Fauzi, A., Rustiadi, E., \& Syaukat, Y. (2015, Desember). Kinerja Program Nasional Pemberdayaan Masyarakat Mandiri Perdesaan di Kabupaten Bandung, MIMBAR. pp. 307-318. 